\title{
Interaction of alcohol and tobacco as risk factors in cancer of the laryngeal region
}

\author{
JØRN OLSEN, ${ }^{1}$ SVEND SABREO ${ }^{2}$, AND ULLA FASTING ${ }^{2}$ \\ From the Institute of Community Health ${ }^{1}$ Department of Social Medicine, University of Odense, JB \\ Winsløwsvej 17, DK-5000 Odense C, and the Institute of Social Medicine, ${ }^{2}$ University of Aarhus, Denmark
}

SUMMARY The aim of this study is to present risk assessments for the combined effect of alcohol and tobacco in cancer of the larynx. The case control study included all newly diagnosed laryngeal cancer patients under the age of 75 in Denmark during the years 1980-2. Four age and sex matched controls were selected using the municipal person registry in which the case was listed. Ninety six per cent of all cases and 78\% of controls participated in the study, which is based on 326 cases and 1134 controls. Information on alcohol consumption and tobacco use was obtained by means of mailed questionnaires. For all laryngeal cancers as well as for the subgroups concerning cancer of the glottis and supraglottis alcohol consumption and tobacco use were found to be important risk factors. The effect of joint exposure was greater than the effect predicted from the sum of effects of each factor acting separately. Thus the combined effect follows a multiplicative rather than additive model.

The larynx is the site of $1.5 \%$ of all new cases of cancer among Danish males and of $0.3 \%$ among females. ${ }^{1}$ Cancer of the larynx is still a rare disease, but the incidence rates have increased during recent decades, especially among males. ${ }^{2}$

The association between alcohol and tobacco and laryngeal cancer is well known,,$^{3-8}$ but the quantitative effect of alcohol and tobacco combined has only recently been studied. ${ }^{7}$ This paper adds risk assessment for the combined effect of alcohol and tobacco according to site specific cancers of the larynx.

The data used were collected primarily to study the possible occupational aetiology of laryngeal cancer. ${ }^{9}$

\section{Materials and methods}

The investigation was performed as a case control study. All newly diagnosed laryngeal cancer patients in Denmark during the period March 1980 to March 1982 under 75 years of age at the time of diagnosis were selected as cases. The cancer patients were ascertained from the five departments involved in laryngeal cancer therapy in Denmark. For each case, four controls were identified using the municipal person registry in which the case was listed. Controls were matched to cases according to sex and closest possible date of birth. For 38 cases only three controls were selected from the municipal person registry.

Both cases and controls received a self administered questionnaire, which included questions about previous work history and use of tobacco and alcohol. Detailed questions were asked about present and past smoking and drinking habits, when the smoking habit started, amount and type of alcohol and tobacco used, and the estimated average life time tobacco use and alcohol consumption. All questions were asked in a closed form. Medical information concerning cancer patients was abstracted from hospital files by nurses collaborating with the project.

Controls were contacted up to three times in the case of no response. Questionnaires with missing data were returned, and cases and controls were offered an interview by phone (controls) or by the participating nurse (cases).

The unit of measurement of alcohol in the analysis is estimated alcohol in grams $(10 \mathrm{~g}$ is approximately equivalent to the alcohol content of one beer, one glass of wine or one schnapps, the unit of measurement in the data collection). The unit of measurement of tobacco is $1 \mathrm{~g}$, equivalent to the tobacco content of one cigarette. The tobacco 
content of one cigar was set at $3 \mathrm{~g}$ and a pipeful at $2.5 \mathrm{~g}$. The total consumption of alcohol and tobacco was calculated by multiplying the reported average consumption by consumption years.

For the statistical analyses the Mantel-Haenszell test $^{10}$ was used along with logistic regression. ${ }^{11}$

\section{Results}

Altogether 375 cases were identified but 34 of these were not laryngeal cancers: 32 were in the hypopharynx and 2 in the oropharynx. Fifteen cases (4\%) declined to take part in the study.

There were 1462 controls, of whom 328 (22\%) declined to take part leaving 1134 controls in the study.

The site of the laryngeal cancers and the sex of the patients are shown in table 1 . There were 191 cancers of the glottis, 111 of the supraglottis, and 24 of the infraglottis or not classified. The male:female ratio was 5.5 for all cases but 24.5 for cancers of the supraglottis.

Table 1 Laryngeal cancers by site, histological type, and sex.

\begin{tabular}{llllllll}
\hline & \multicolumn{3}{l}{ Histological type } & & \multicolumn{2}{l}{ Sex } \\
\cline { 2 - 3 } \cline { 6 - 7 } Site & $\begin{array}{l}\text { Squamous cell } \\
\text { carcinoma }\end{array}$ & $\begin{array}{l}\text { Other types or } \\
\text { not defined }\end{array}$ & & Male & Female & Total \\
\hline Glottis & 176 & 15 & 176 & 15 & 191 \\
Supraglottis & 101 & 10 & 79 & 32 & 111 \\
Subglottis & 10 & 2 & 11 & 1 & 12 \\
Larynx NOS & 4 & 3 & 5 & 2 & 7 \\
Unknown & 5 & 0 & & 5 & 0 & 5 \\
Total & 296 & 30 & 276 & 50 & 326 \\
\hline
\end{tabular}

The association between all laryngeal cancers and the average lifetime use of tobacco and alcohol is shown in tables 2 and 3 , which demonstrate that alcohol consumption and tobacco use are both associated with an increased risk of cancer of the larynx. Of the smokers in the case group $81 \%$ reported that they normally inhaled tobacco smoke compared to $69 \%$ of the smokers in the control group $(\mathrm{p}<0.01)$.

Similar results are seen for cancer of the supraglottis and glottis in tables 4 and 5 . Only a very $\underset{\overrightarrow{\mid}}{\overrightarrow{\mid}}$ moderate increased risk is seen for the non-smokers with a moderate alcohol consumption.

The associations with average alcohol $\frac{9}{m}$ consumption and tobacco use seem to be similar for $\mathbb{D}$ the two sites. A similar result was found when lifetime exposures were considered.

More cancer patients, regardless of the site of the $\overrightarrow{0}$ cancer, reported beer as the most frequently drunk alcoholic beverage (table 5).

In table 6, interaction between alcohol and tobacco $\frac{\widehat{D}}{}$ is estimated by using a parameter proposed by

Table 3 Age and sex adjusted risk ratios of laryngeal canc $\overrightarrow{8}$ for combined exposure to alcohol and tobacco (average 응 consumption and use)

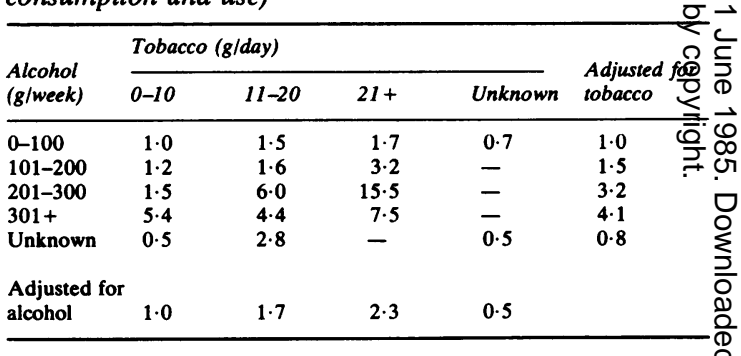

Table 2 Classification of laryngeal cancer patients and controls according to consumption of alcohol and tobacco use

\begin{tabular}{|c|c|c|c|c|c|c|}
\hline \multirow{2}{*}{$\begin{array}{l}\text { Alcohol } \\
\text { (g/week) }\end{array}$} & \multicolumn{5}{|c|}{ Tobacco (g/day) } & \multirow{2}{*}{$\begin{array}{l}\text { All } \\
\text { subjects }\end{array}$} \\
\hline & & $0-10$ & $11-20$ & $21+$ & Unknown & \\
\hline $0-100$ & $\begin{array}{l}\text { Cases } \\
\text { Controls }\end{array}$ & $\begin{array}{l}129 \\
592\end{array}$ & $\begin{array}{r}49 \\
159\end{array}$ & $\begin{array}{l}19 \\
49\end{array}$ & $\begin{array}{r}2 \\
13\end{array}$ & $\begin{array}{l}199 \\
813\end{array}$ \\
\hline $101-200$ & $\begin{array}{l}\text { Cases } \\
\text { Controls }\end{array}$ & $\begin{array}{l}23 \\
84\end{array}$ & $\begin{array}{l}19 \\
57\end{array}$ & $\begin{array}{l}13 \\
18\end{array}$ & $\begin{array}{l}0 \\
3\end{array}$ & $\begin{array}{r}55 \\
162\end{array}$ \\
\hline $201-300$ & $\begin{array}{l}\text { Cases } \\
\text { Controls }\end{array}$ & $\begin{array}{r}9 \\
28\end{array}$ & $\begin{array}{l}13 \\
15\end{array}$ & $\begin{array}{l}7 \\
2\end{array}$ & $\begin{array}{l}\mathbf{0} \\
\mathbf{0}\end{array}$ & $\begin{array}{l}29 \\
45\end{array}$ \\
\hline $301+$ & $\begin{array}{l}\text { Cases } \\
\text { Controls }\end{array}$ & $\begin{array}{r}8 \\
10\end{array}$ & $\begin{array}{l}9 \\
9\end{array}$ & $\begin{array}{r}12 \\
7\end{array}$ & $\begin{array}{l}0 \\
0\end{array}$ & $\begin{array}{l}29 \\
26\end{array}$ \\
\hline Unknown & $\begin{array}{l}\text { Cases } \\
\text { Controls }\end{array}$ & $\begin{array}{r}6 \\
58\end{array}$ & $\begin{array}{l}6 \\
9\end{array}$ & $\begin{array}{l}\mathbf{0} \\
\mathbf{3}\end{array}$ & $\begin{array}{r}2 \\
18\end{array}$ & $\begin{array}{l}14 \\
88\end{array}$ \\
\hline All subjects & $\begin{array}{l}\text { Cases } \\
\text { Controls }\end{array}$ & $\begin{array}{l}175 \\
772\end{array}$ & $\begin{array}{r}96 \\
249\end{array}$ & $\begin{array}{l}51 \\
79\end{array}$ & $\begin{array}{r}4 \\
34\end{array}$ & $\begin{array}{r}326 \\
1134\end{array}$ \\
\hline
\end{tabular}


Table 4 Age and sex adjusted risk ratios oflaryngeal cancer by site for combined exposure to alcohol and tobacco (average consumption and use)

\begin{tabular}{|c|c|c|c|c|c|}
\hline \multirow{2}{*}{$\begin{array}{l}\text { Alcohol } \\
\text { (g/week) }\end{array}$} & \multicolumn{4}{|c|}{ Tobacco (g/day) } & \multirow{2}{*}{$\begin{array}{l}\text { Adjusted for } \\
\text { tobacco }\end{array}$} \\
\hline & $0-10$ & $11-20$ & $21+$ & Unknown & \\
\hline \multicolumn{6}{|l|}{ Site: glottis } \\
\hline $0-100$ & $1 \cdot 0$ & $1 \cdot 2$ & $1 \cdot 7$ & $1 \cdot 4$ & $1 \cdot 0$ \\
\hline $101-200$ & $1 \cdot 1$ & $1 \cdot 8$ & 3.9 & - & 1.4 \\
\hline $201-300$ & $1 \cdot 1$ & $5 \cdot 0$ & $19 \cdot 0$ & - & $3 \cdot 2$ \\
\hline $301+$ & $4 \cdot 8$ & 4.9 & $9 \cdot 6$ & - & $5 \cdot 0$ \\
\hline Unknown & $0 \cdot 1$ & $3 \cdot 5$ & - & 0.4 & 0.6 \\
\hline \multirow{2}{*}{$\begin{array}{l}\text { Adjusted for } \\
\text { alcohol }\end{array}$} & & & & & \\
\hline & $1 \cdot 0$ & $1 \cdot 7$ & $2 \cdot 6$ & $1 \cdot 3$ & - \\
\hline \multicolumn{6}{|c|}{ Site: supraglottis } \\
\hline $0-100$ & $1 \cdot 0$ & 1.8 & $1 \cdot 8$ & 0 & $1 \cdot 0$ \\
\hline $101-200$ & 1.4 & $1 \cdot 2$ & 3.4 & 0 & $1 \cdot 3$ \\
\hline $201-300$ & 0.3 & 3.4 & 15.9 & - & $2 \cdot 0$ \\
\hline $301+$ & $3 \cdot 3$ & $3 \cdot 5$ & $6 \cdot 8$ & - & 3.0 \\
\hline Unknown & 0.6 & $1 \cdot 3$ & 0 & 0.6 & 0.6 \\
\hline \multirow{2}{*}{$\begin{array}{l}\text { Adjusted for } \\
\text { alcohol }\end{array}$} & & & & & \\
\hline & $1 \cdot 0$ & $1 \cdot 7$ & $2 \cdot 1$ & 0.3 & - \\
\hline
\end{tabular}

Table 5 Odds ratio of preferred beverage according to origin of the cancer: $95 \%$ confidence limits in parentheses

\begin{tabular}{|c|c|c|c|c|}
\hline \multirow{2}{*}{$\begin{array}{l}\text { Preferred type } \\
\text { of alcohol }\end{array}$} & \multirow{2}{*}{ Adjustment } & \multicolumn{3}{|l|}{ Site of cancer } \\
\hline & & All larynx & Gloutis & Supraglottis \\
\hline Beer & $\begin{array}{l}\text { Unadjusted } \\
\text { Adjusted* }\end{array}$ & $\begin{array}{l}1.5 \\
1.4(1 \cdot 1-1 \cdot 9)\end{array}$ & $\begin{array}{l}2 \cdot 0 \\
1 \cdot 6(1 \cdot 1-2 \cdot 2)\end{array}$ & $\begin{array}{l}1.0 \\
1.2(0.7-1.8)\end{array}$ \\
\hline Wine & $\begin{array}{l}\text { Unadjusted } \\
\text { Adjusted** }\end{array}$ & $\begin{array}{l}0.5 \\
0.6(0.4-0.9)\end{array}$ & $\begin{array}{l}0.4 \\
0 \cdot 6(0 \cdot 4-1 \cdot 1)\end{array}$ & $\begin{array}{l}0.5 \\
0.5(0 \cdot 2-0.9)\end{array}$ \\
\hline Spirits & $\begin{array}{l}\text { Unadjusted } \\
\text { Adjusted* }^{*}\end{array}$ & $\begin{array}{l}0.8 \\
1.0(0 \cdot 6-1 \cdot 8)\end{array}$ & $\begin{array}{l}0.5 \\
0.7(0.3-1 \cdot 6)\end{array}$ & $\begin{array}{l}1.2 \\
1.5(0.7-3.3\end{array}$ \\
\hline
\end{tabular}

*Adjusted for age (years), sex, socioeconomic group (independent, salary worker, skilled worker, semiskilled worker, and others), average tobacco use and alcohol consumption (in three groups) by the regression model.

Table 6 Rothman's index of interaction

\begin{tabular}{llcc}
\hline \multirow{2}{*}{$\begin{array}{l}\text { Alcohol } \\
\text { (g/week) }\end{array}$} & Sobacco (g/day) \\
\cline { 3 - 4 } $101-200$ & Site & $11-20$ & $21+$ \\
\hline \multirow{2}{*}{$201+$} & All larynx & $0 \cdot 8$ & $2 \cdot 2$ \\
& Supraglottis & $-0 \cdot 1$ & $2 \cdot 4$ \\
& Glottis & $2 \cdot 5$ & $3 \cdot 3$ \\
& All larynx & $2 \cdot 2$ & $4 \cdot 7$ \\
& Supraglottis & $1 \cdot 2$ & $5 \cdot 0$ \\
& Glottis & $3 \cdot 5$ & $6 \cdot 1$ \\
\hline
\end{tabular}

Rothmann, ${ }^{12}$ which is the ratio of the observed effect of joint exposure to the effect predicted from the sum of effects of each factor acting separately. A value of 1.0 indicates no synergy, that is, the effects are additive on a non-transformed scale. A value greater than 1.0 indicates synergy, that is, the number of cases of laryngeal cancer among those exposed to both alcohol and tobacco is more than would be expected if the effects were additive. Synergy is seen for all exposure combinations except for moderate alcohol consumption and tobacco use.

\section{Discussion}

If heavy drinking and smoking are more predominant among non respondents, the risk ratios for smoking and drinking will be overestimated, since most of the non respondents belong to the control group. All we know about the refusal rate is that it was highest in the rural areas and among the oldest subjects.

Controls were ascertained in order to secure internal validity rather than to match cases and controls, and all analyses are performed on unmatched data. Controls "belonging" to the excluded 34 cancers of the hypopharynx and oropharynx are not therefore excluded from the case group. These excluded cases had a similar sex ratio and, more important, they had a similar geographical residence as did the rest of the cases.

It is obviously difficult to obtain accurate smoking and drinking histories, but if the misclassification is unrelated to the disease under study and unrelated to the other lifestyle variables, it could not account for the interaction reported in the study.

Residual confounding between alcohol and tobacco within categories might lead to overestimation of the interaction parameter. However it is unlikely that residual confounding will account for the entirety of the synergistic relation between the two factors. ${ }^{7}$

A clearer indication of synergism was seen when the exposure was based on average alcohol consumption and tobacco use compared to life-time use, as was found by Flanders and Rothmann. ${ }^{7}$ Interaction was found regardless of the site of the cancer. The public health implication of an effect of joint exposure greater than additive is the improved prospect for prevention by intervention aimed at excess of either of the risk factors. ${ }^{7}$

A reduction in alcohol consumption in France during the second world war was followed by a decreased incidence of laryngeal cancer, in spite of no reduction in tobacco use. ${ }^{13}$

Jensen $^{14}$ studied a group of Danish brewery workers whose consumption of beer was estimated to be four times greater than that of the general male population in Denmark. An excess of laryngeal cancers was found in this group.

In this study cancer patients drank alcohol more often in the form of beer, but this association is not 
necessarily of a causal nature. It might be the result of confounding by social class, since beer drinking is more predominant among working class people, who have a high incidence rate of laryngeal cancer. ${ }^{15} \mathrm{We}$ have included broad socioeconomic groups in the statistical model which did reduce the odds ratio, but residual confounding could explain the remaining association. Whether or not beer is a special risk factor for laryngeal cancer needs to be studied further.

We thank the following for their cooperation: Kirsten Haue-Pedersen, Hanne Lundsgaard Jensen, Meta Thye Pedersen, Inge Kjelstrup, Bente Bislev, Margrethe Larsen, Birgit Jansen, Karen Kristensen, Karen Margrethe Pedersen, Kirsten Pryds Jensen, Kirsten Bork Nielsen, Hanne Sand Hansen, Birthe Dam Nielson, and Anni Overdal Poulsen.

The study was supported by grants from the Danish Medical Research Council (12-9449, 12-2819).

Requests for reprints to: Jørn Olsen, Institute of Social Medicine, Vesterbro Torv 1-3, DK 8000 Aarhus C, Denmark.

\section{References}

${ }^{1}$ Danish Cancer Registry. Incidence of cancer in Denmark 1973-1977. Copenhagen: Danish Cancer Society, 1982.
${ }^{2}$ Clemmesen J. Statistical studies in the aetiology of malignant neoplasma v. Acta Pathol Microbiol Scand 1977, Suppl 261.

${ }^{3}$ Wynder EL, Bross, IJ, Day E. A study of environmenta factors in cancer of the larynx. Cancer 1956; 9: 86-110

${ }^{4}$ Wynder EL, Cobey LS, Mabuchi K, Mushinski M Environmental factors in cancer of the larynx. Cance? 1976; 38: 1591-601.

${ }^{5}$ Hinds MW, Thomas DB, O'Reilly HP. Asbestos, denta $x$-rays, tobacco, and alcohol in the epidemiology of laryngeal cancer. cancer 1979; 44: 1114-20.

${ }^{6}$ Rothman KJ, Cann CI, Flanders D, Fried MP: Epidemiology of laryngeal cancer. Epidemiol Reviews 1980; 2: 195-209.

${ }^{7}$ Flanders WD, Rothman KJ. Interaction of alcohol an tobacco in laryngeal cancer. Am J. Epidemiol 1982; 115.므 371-9.

${ }^{8}$ Hansen HS. Neoplasma malignum larynis. Copenhagen Polyteknisk forlag, 1975.

${ }^{9}$ Olsen J, Sabroe S. Lajer M. Welding and cancer of the larynx. Eur J Cancer Clin Oncol. 1984, 20, 639-43.

${ }^{10}$ Mantel N, Haenszel W. Statistical aspects of the analysis $\overrightarrow{0}$ of data from retrospective studies of disease. $J$ Nat ${ }^{-}$ Cancer Inst 1959; 22: 719-48. ${ }^{11}$ Breslow NE, Day NE. Statistical methods in cancer

${ }^{12}$ Rothman KJ. The estimation of synergy or antagonism $?$ Am J Epidemiol 1976; 104: 506-11.

${ }^{13}$ Tuyns AJ, Audigier JC. Double wave cohort increase for oesophogeal and laryngeal cancer in France in relation to reduced alcohol consumption during the secorf 5 world war. DIGEST 1976; 14: 197-208.

${ }^{14}$ Jensen OM. Cancer morbidity and causes of death amo요윽 Danish brewery workers. Lyon: 1980.

${ }^{15}$ Olsen J, Sabroe S. Occupational causes of laryngeal cancer. J Epidemiol Community Health 1984, 117-21. 